\title{
Franz Peter Schubert y el estigma de la sífilis
}

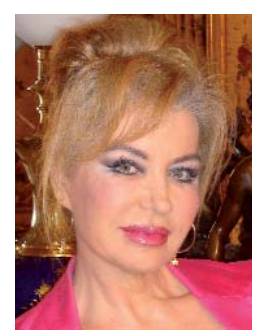

Aurora Guerra Tapia

Profesora titular

de Dermatología.

Universidad Complutense de Madrid.

Jefa de la Sección de Dermatología.

Hospital Universitario

12 de Octubre. Madrid
Seleccionar las palabras justas que enlacen en la cabecera de un texto el nombre de un músico glorioso como es el austriaco Franz Peter Schubert (1797-1828) y una enfermedad vergonzante como es la sífilis resulta casi imposible: la música, poesía del sonido y del silencio, fruto del amor entre la armonía y el ritmo, beso del alma al aire; la sífilis, enfermedad manchada, ocultada, disimulada, negada, como otras muchas enfermedades infecciosas en las que su adquisición presupone un pecado, un yerro en la moral individual o, lo que es peor a los ojos de muchos, un desliz en la moral social. Un espinoso maridaje.

Franz nace el 30 de enero de 1797 en el suburbio vienés de Himmelpfortgrund. Su sensibilidad musical propia de un genio se manifiesta ya a los 8 años de edad. Su profesor, Michael Holzer, reconoce emocionado: «No le doy clase, sino que disfruto escuchando sus

\author{
Ave Maria! Jungfrau mild, \\ Erhöre einer Jungfrau Flehen, \\ Aus diesem Felsen starr und wild \\ Soll mein Gebet zu dir hin wehen. \\ Wir schlafen sicher bis zum Morgen, \\ Ob Menschen noch so grausam sind. \\ O Jungfrau, sieh der Jungfrau Sorgen, \\ O Mutter, hör ein bittend Kind! \\ Ave Maria!*
}

maravillas... El conocimiento lo ha recibido del buen Dios».

Su relación con las enfermedades dermatológicas comienza también en la más tierna infancia. La viruela, afección infecciosa causada por Variola virus, con una altísima tasa de mortalidad, declarada erradicada para la humanidad, gracias a la vacunación, el 8 de mayo de 1980, debió hacer presa en la piel de Schubert cuando era muy niño. Solo tenemos información indirecta de este padecimiento gracias a su temprano ingreso en el coro de la capilla imperial, que imponía como requisito inexcusable haber sobrevivido a la terrible enfermedad. El certificado médico del diagnóstico superado era la primera condición.

A partir de ahí, durante años, se forma en la composición e interpretación de forma intensa. Antonio Salieri, controvertida figura de innegable valor musical, instruye al joven en el arte

* Ave María! Mansa doncella / Escucha la oración de una doncella / Tú puedes salvar en medio de la desesperación. / Seguros podemos dormir bajo tu cuidado, / aunque exiliados, marginados e injuriados. / Doncella Oye la oración de una doncella, / ¡Madre, oye a una hija suplicante! / ¡Ave María! 
que ya dominaba de forma intuitiva. Con solo 17 años, estrena su Misa número I en fa mayor con éxito incuestionable. Solo en el año 1815, compone la increíble cifra de 144 lieder (poema de alto contenido emocional), aparte de sinfonías, misas, sonatas, etc. Aun así, sus dificultades económicas son grandes, y los fracasos, estruendosos. Como tantos artistas, surca con violencia las sombras de la gloria (fig. 1).

Tímido, sensible y tal vez, según algunos de sus biógrafos, con un trastorno bipolar, sus amores son difíciles. En 1814, se enamora de Theresa Grob, la soprano que había interpretado su misa. En 1818, le llega una nueva pasión, la doncella Pepi Pöckelhofer. Pero, junto a estas protagonistas conocidas de su paisaje sentimental, las relaciones azarosas, eventuales, son múltiples.

$\mathrm{Al}$ final de 1822, adquiere el irreparable mal, que da sus primeros síntomas en enero de 1823. Ingresa en el Hospital General para someterse a tratamiento durante semanas, pero, pese a esta evidencia, oculta su dolencia a propios y extraños, alegando que se retira para trabajar en nuevas obras. A finales del año, sobreviene un empeoramiento, del que poseemos datos gracias a la carta que Moritz von Schwind, ilustrador de sus canciones, escribe al poeta Franz von Schober, uno de

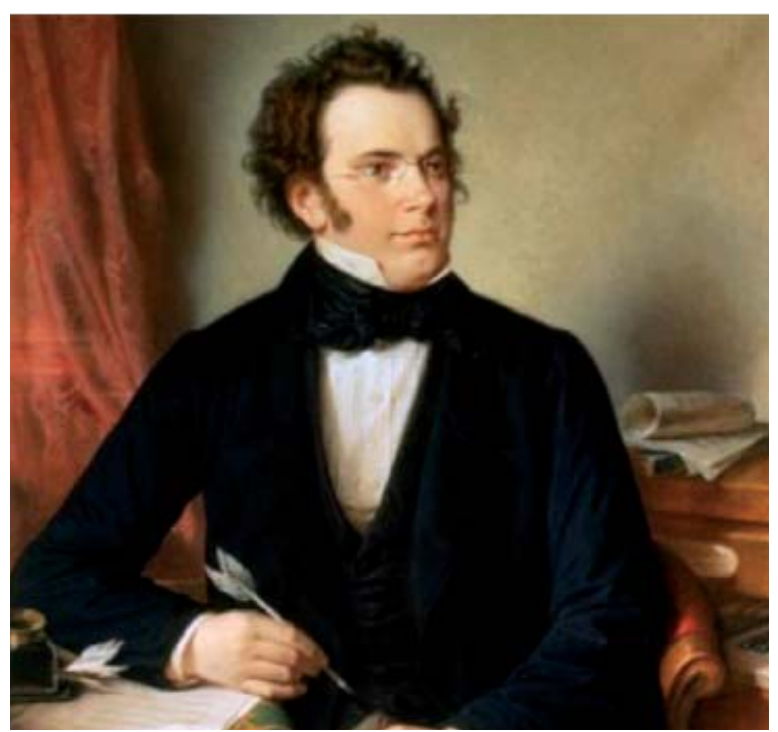

Figura 1. Franz Peter Schubert (1797-1828). los muchos colegas que le acogen en su casa: «Tiene de nuevo su propio cabello, que debe ser cortado a causa del exantema...". "Bebe mucho té y a menudo se baña..."

En el diario de Eduard von Bauernfeld, escritor y amigo, aparece una alusión a la sífilis cuando menciona que la enfermedad de Schubert es la misma que padeció el gran artista florentino Benvenuto Cellini (1500-1571), escultor, grabador y escritor excelso, pero a la vez hombre mundano con devaneos sexuales, que sufrió el mal según todas las fuentes.

Continúa su fecundidad compositiva en los momentos de mejoría, que se siguen de intensa depresión y desfallecimiento. Sufre graves cefaleas y mareos. Bauernfeld escribe el día 17 de noviembre de 1828: «Permanece agotado, con la cabeza ardien$d o$, y en la tarde ha comenzado a tener alucinaciones...». A las 3 de la tarde del día 19, exhausto y febril, expira.

Nada podemos afirmar con seguridad sobre su historia médica. Sin embargo, la insistencia en ocultar su mal -una enfermedad que generaba el más profundo desprecio-, la existencia de la alopecia, la roséola diseminada y las cefaleas hacen pensar en una sífilis secundaria. Por otra parte, las referencias al tratamiento pueden corresponder a derivados mercuriales (los preparados con té podían contenerlo), y los baños podían ser los que se prescribían para preparar la piel para la terapia. Aunque en su certificado de defunción figura el tifus como causa última, es sabido que, en el siglo XIX, cualquier proceso con fiebre y alteración mental se denominaba fiebre nerviosa o tifus.

El nombre de sífilis proviene del poema épico del cirujano veronés Girolamo Fracastoro, titulado Sýphilis sive morbus gállicus. Cuenta la leyenda que el pastor Siphylus, junto a sus camaradas, desafía al dios Apolo, que los castiga con la terrible enfermedad venérea (de Venus, la diosa romana del amor).

Hoy sabemos que la sífilis es una infección adquirida por contacto sexual, causada por la bacteria Treponema pallidum. Millones de personas la padecen en el mundo, pero sigue siendo innombrable. Una enfermedad del cuerpo, un estigma del alma. 